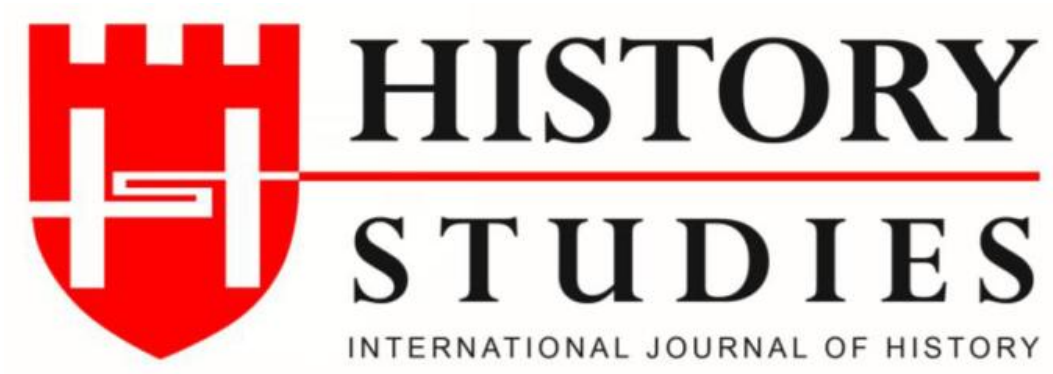

ISSN: 13094173 (Online) 1309 - 4688 (Print)

Volume 12 Issue 4, August 2020

DOI Number: 10.9737/hist.2020.885

Araştırma Makalesi

Makalenin Geliş Tarihi: 19.05.2020 Kabul Tarihi: 15.06.2020

Atıf Künyesi: Özlem Atalan, “Learning from Hall and Room Arrangements; Examples from Kula Manisa Traditional Houses", History Studies, 12/4, Ağustos 2020, s. 1441-1464.

\title{
Learning from Hall and Room Arrangements; Examples from Kula - Manisa Traditional Houses
}

\author{
Geleneksel Oda-Sofa Düzenlemelerinden Ögrendiklerimiz; Kula- Manisa \\ Geleneksel Konutları
}

\author{
Assoc. Prof. Dr. Özlem Atalan \\ ORCID No: 0000-0002-9772-1642 \\ Manisa Celal Bayar University
}

\begin{abstract}
Anatolian traditional housing architecture is an important part of our architectural history with its architectural features and design principles. The buildings are arranged in plan fiction, living, and service units, as a whole within themselves. Kula traditional residences reflect the architectural features of the "Turkish House" or the "Ottoman House" with its location in the center of Anatolia. The buildings were built from the beginning of the 17th century until the beginning of the 20th century. However, the traditional architecture of the process from the late 18 th to the early 20 th century has reached today. When looking at the traditional houses in Anatolia in terms of planning architectural elements, it can be said that two basic elements are at the forefront. These are "rooms" and "halls" which are common areas between rooms. Within the scope of the study, the design fiction of the rooms and halls of Anatolian traditional housing was examined. Also, evaluations regarding Kula houses, rooms, and sofa connections have been made.
\end{abstract}

Keywords: Traditional House, Traditional Room, Hall, Kula, Manisa

Öz: Anadolu geleneksel konut mimarisi; mimari özellikleri ve tasarım ilkeleriyle mimarlık tarihimizin önemli bir parçasıdır. Yapılar, plan kurgusunda, yaşama ve servis birimleriyle, kendi içlerinde bir bütün olarak düzenlenmiştir. Kula geleneksel konutları, Anadolu'nun merkezinde yer alan konumuyla, Türk evinin yada Osmanlı evinin tüm mimari özelliklerini yansıtır. Yapılar, 17. yüzyıl başından itibaren, 20. yüzyıl başına kadar inşa edilmiştir. Ancak, günümüze, genellikle 18. yüzyılın sonlarından, 20. başlarına kadar ki sürece ait konut mimarisi ulaşabilmiştir.

Anadolu'daki geleneksel konutlara mimari öğelerinin planlanması yönüyle bakıldığında, iki temel öğenin ön planda olduğu söylenebilir. Bunlar "odalar" ve "odalar arası ortak alan olan sofa" mekanlarıdır. Çalışma kapsamında, Anadolu geleneksel konutlarının, oda ve sofalarının tasarım kurgusu kapsamlı olarak incelenmiştir. Bununla birlikte, Kula evlerinin, oda ve sofa bağlantılarına ilişkin değerlendirilmeler yapılmıştır.

Anahtar Kelimeler: Geleneksel Konut, Türk evi, Geleneksel oda, Sofa, Kula, Manisa 


\section{Introduction}

The traditional architectural environment can be said as the reflection of the whole generation from generation to generation, common aesthetics and values to life. The traditional Anatolian house, the Turkish house or the Ottoman house, is shaped by the planning of its street and neighbourhood with social, economic, ethnic, and natural elements. Environmental conditions have been effective in the construction of traditional houses. Wood structures were used in the regions where the timber was dominant and stone structures were applied in the regions where the quarries were located. Rapoport, who has important works on traditional houses and rural architecture; in interpreting these structures, he states that they are formed by the combination of diversity from whatever culture ${ }^{1}$. He underlines that the structural elements of traditional houses and rural architecture, in particular, are evolutionarily formed elements.

It is stated in Bektaş that the traditional house architecture did not arise from in a few centuries, and that the characteristics of the Turkish house date back to the Hittites ${ }^{2}$. However, apart from the examples of Amcazade Hüseyin Paşa Residence dated 1699 and some house which dates back 300 ago in Safranbolu is survived in Anatolia to today. The sustainability of urban historical sites is important in this context.

Especially before the 20th century, a great housing tradition, culture, and life were formed in Anatolian cities. This housing architecture has changed as various plan types. Traditional houses were built widely from the beginning of the 17th century until the beginning of the 20th century. However, today, generally, the architecture of the dwelling from the 19th and early 20 th centuries has survived.

Sezgin stated that at the beginning of factors that make the local residential architecture in Turkey are geography, traditions and way of life that the arrival of religious behaviour ${ }^{3}$. Anatolia and Rumelia in the Ottoman Period had a rural economic system based on agriculture and including animal husbandry. In this process, the rural houses had a more archaic appearance than those in the cities. Generally, the ground floor was used as a place where yields were stored or animals were housed.

\section{Methods}

When looking at the traditional residences in Anatolia in terms of planning architectural elements, it can be said that two basic elements are at the forefront. These are hall spaces, which are common areas between rooms and rooms. The study started with the observations and measurements made in the traditional urban texture of Kula, and the identification of existing traditional residences, rooms and halls. Examples were selected within registered residential buildings within the Kula Urban Conservation Area. Some of selected traditional structures are in ruins today. Others have been restored. Scope of study, 20 traditional houses has been studied. The connections of the rooms and hall sections of these houses were examined. However, in order to examine the study sufficiently, firstly, the room and hall space features of the Anatolian traditional houses were investigated. In this context; scope of study;

- The general architectural features and room- sofa connections of the traditional Turkish House were examined.

\footnotetext{
${ }^{1}$ Amos Rapoport, "Theory, Culture and Housing,", Housing, Theory And Society, Vol. 17, No. 4, 2000, s. $145-165$.

${ }^{2}$ Cengiz Bektaş, Türk Evi, Yem Yayın, İstanbul, 2013, s.100

${ }^{3}$ Haluk Sezgin, Yöresel Konut Mimarisi ve Türkiye'deki Örnekleri Hakkında, Tasarım ve Kuram, sayı 4, Mayıs, 2006 İstanbul, s. 6
} 


\footnotetext{
- Room-hall architectural features and their connections were examined in Kula traditional houses.

- Evaluations and suggestions were made regarding the room and hall arrangements of Kula traditional residences.

\section{The Process of Creating Traditional Anatolian House and the Connections between Hall and Room}

\subsection{The Process of Creating Traditional Anatolian House}

Traditional residential architecture is a type of dwelling that occurred in Rumelia and Anatolian regions within the borders of the Ottoman State and continued for 600 years ${ }^{4}$. Turks who accept Islam have created living places in Anatolia in line with both their past traditions and their new beliefs. The origins of the Anatolian traditional residence date back to the nomadic period or Turks. As a result of the settling of the nomadic Turks coming to Asia from the Asian steppes to Anatolia, the formation process of the Turkish dwellings that they built as a protective "living space" had begun".
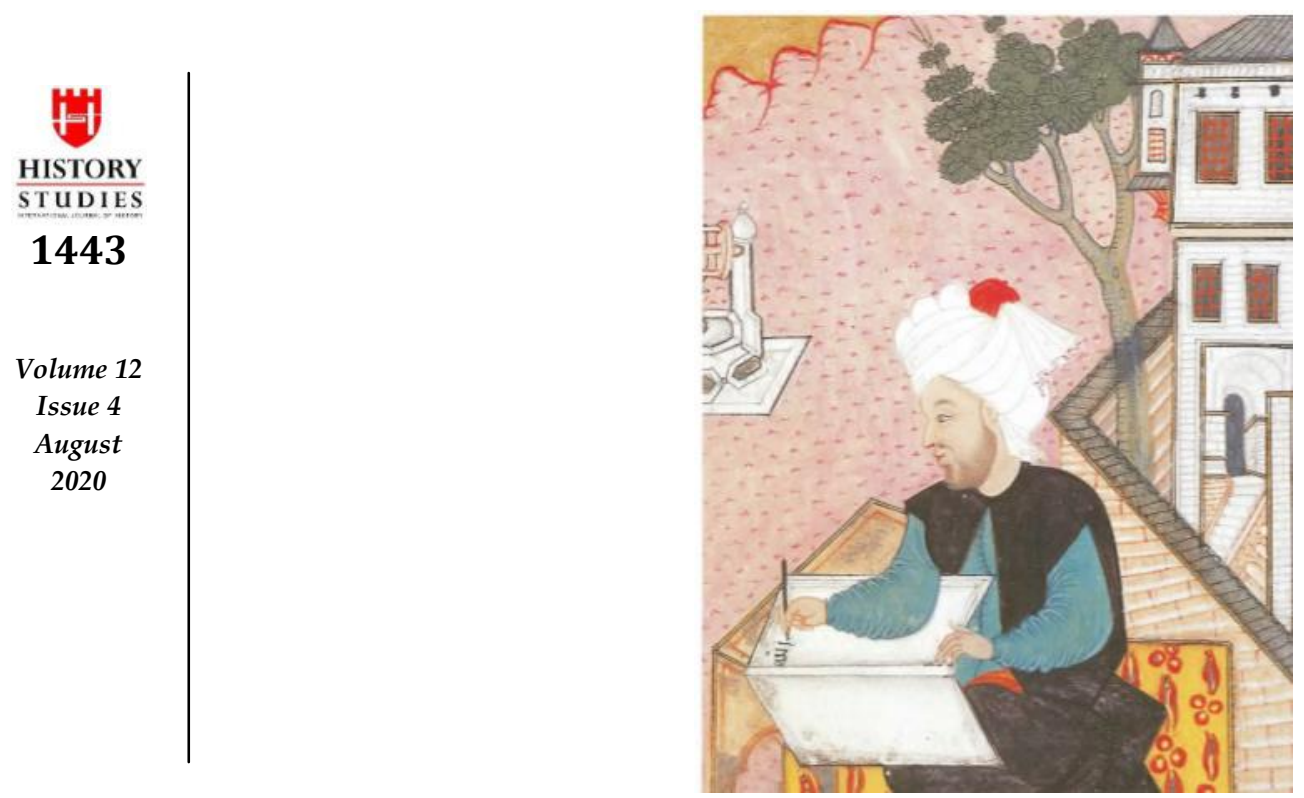

Figure 1. House Miniature, (Tercüme-i Şakay-1 Numaniye) 17. Century ${ }^{6}$

Tents used as living units during the nomadic period, which were contributed to the formation of Turkish houses and rooms. According to Yurekli, the formation of summer and winter rooms in the traditional house was formed by the reflection of nomadic life on Turkish architecture ${ }^{7}$. The nomadic family migrated from the heat of the summer to the coolness of the mountains and plateaus, and to the warm regions of the winter. This meant that the family

\footnotetext{
${ }^{4}$ Bektaş, age, s. 100 .

5 Önder Küçükerman, Kendi Mekanının Arayışı Iç̧inde Türk Evi. Türkiye Turing Ve Otomobil Kurumu, İstanbul, 1991, s.10.

${ }^{6}$ Doğan Kuban, Türk Hayatlı Evi, Eren Yayınları, İstanbul, 1995, s.49.

${ }^{7}$ Ferhan Yürekli- Hülya Yurekli, Türk Evi- The Turkish House, Birinci Baskı, Yem Yayın, İstanbul. 2005, s.16.
} 
living in the Turkish house moved to the upper floors in the winter. Also, on the contrary, the family moves to cooler rooms, a halls or a courtyard during the summer months.

Eldem mentions the "Turkish house", which was formed by the reflection of Anatolian life culture on housing construction. Traditional residences are also defined as type of plan with hall (sofas) ${ }^{8}$. According to Kuban, the house plan type with a hall is a rural design developed by the Turkish agricultural community in Anatolian rural areas. Ottoman society is under the influence of Islam in this development process of housing. The introverted life of Islamic women has been an effective factor in housing design ${ }^{9}$.

Kuban states that starting from the 12th century; Central Anatolia under the Seljuk rule is known as "Turchia" 10 . The peculiar qualities of the Anatolian-Turkish society began to form in the first centuries of the Ottoman period, in the Central-Western Anatolia and the Balkans. The term "Turkish House" includes residential traditions, consisting of different cultural elements. Unlike the "Ottoman House", which is a general title, it belongs to a certain cultural area. For example, "Kios" or "Foca- Izmir houses" are Ottoman houses with their unique characters ${ }^{11}$.

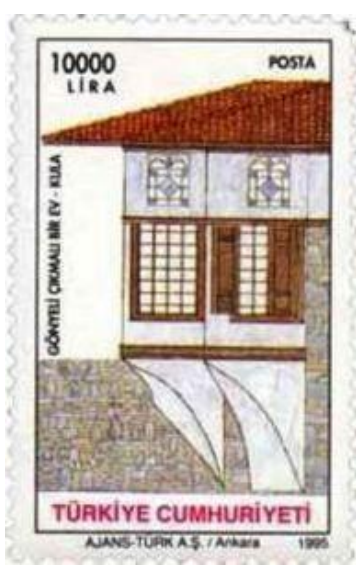

Figure 2. Traditional Kula Houses on Turkey Republic of Stamps ${ }^{12}$

Turkish culture is to extend the extensions of pre-Turkish Anatolian traditions to the new Turkish period. In contrast, for writers of European, Balkan or Arab origin, the term Ottoman has the flexibility to sustain nationalist designs. Although it is clear that the term Ottoman was a suitable use for some institutions, it was insufficient to describe the multi-faceted cultural life of the Ottoman Empire. It is difficult to bring together Crimean Tatars, Egyptian fellahs and Montenegrin peasants, their attitudes towards life ${ }^{13}$.

In terms of reflecting the Anatolian culture, the most important feature of the Turkish traditional residence is the room-sofa sections and their variety combinations. However, Küçükerman underlines the architectural similarity (parallel) between the room and the nomadic tent as a living unit ${ }^{14}$. The family, living a nomadic life, migrated from the heat of summer to the coolness of mountains and plateaus. In winter, it was transported to warm

\footnotetext{
${ }^{8}$ Sedat Hakkı Eldem, Türk Evi Plan Tipleri, İstanbul Teknik Üniversitesi, Mimarlık Fakültesi Yayınları, İstanbul, 1955, s. 70.

${ }^{9}$ Doğan Kuban, Osmanlı Mimarisi, Yem Yayın, İstanbul 2007, s.25.

${ }^{10}$ Kuban, age, s.22.

11 age, s. 22.

12 URL 1- http://www.pulhane.com/KatalogSayfalari/k197813.html

13 age, s. 22.

${ }^{14}$ Küçükerman, age, s.59.
}

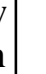


settlements. The family, who lived in the traditional residence, moved from the upper floors to the middle floors in the winter. In summers, they are moved to cooler rooms, a hall or a courtyard.

In Anatolia, traditional houses are lined up on the edges of the streets with organic street texture. The main entrances of the buildings are located on these streets. Traditional Anatolian dwelling has generally few floors. However, over time, the number of floors of the buildings has increased. It has been planned with the understanding that the upper floors of the buildings are always more valuable than the lower floors. Living spaces are located on these floors ${ }^{15}$.

In Anatolia, traditional houses are lined up on the edges of the streets with organic street texture. The main entrance to the house is located through the courtyard wall on the street facade. Anatolian houses have generally few floors. However, over time, the number of floors of the structures has increased. It has been planned with the understanding that the upper floors of the buildings are always more valuable than the lower floors. Living spaces are located on these floors ${ }^{16}$.

According to Yurekli, the upper floor plan of the Turkish house is accepted as the main floor ${ }^{17}$. The reason for this; there may be an idea that the upper floor is a more important location than the others. The main parts of the planning scheme are the room, iwan, and hall sections. The rooms, hall, and courtyard integrate with each other and they are connected by stairs.

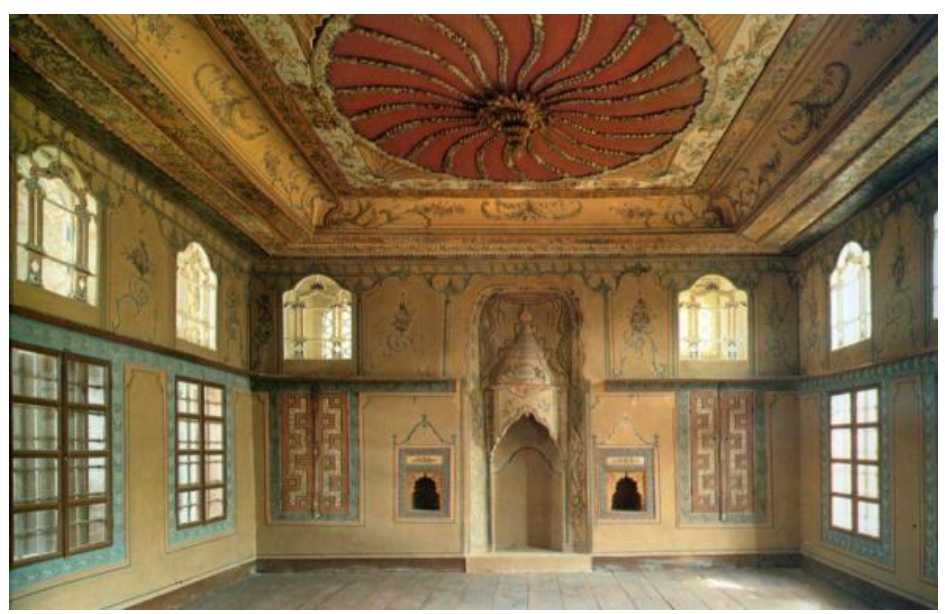

Figure 3. Çakırağa Houses and its room, Birgi, Ödemiş, İzmir

Kuban states that the core plan of the traditional residence is composed of room and hall sections ${ }^{18}$. Gallery floor elements such as room, sofa, service areas, courtyard, or kiosk opening to the courtyard are seen in the planning scheme with different arrangements. Service areas are located on the ground floor of the houses. These areas are hayloft; storage, toilet, kitchen, barn, coop, etc. sections that serve daily life. The rooms on the upper floors are units where living functions such as sitting, eating, working, sleeping are performed. The hall and the courtyard both play a binding role between rooms.

\footnotetext{
${ }^{15}$ Eldem,age.s. 14.

${ }^{16}$ Küçükerman, age, s.59.

${ }^{17}$ Yürekli-Yürekli, age, s.10

18 Doğan Kuban, "Türk Ev Geleneği Üzerine Gözlemler” Türk ve İslam Sanatı Üzerine Denemeler, Arkeoloji ve Sanat yayınları, İstanbul 1982, s. 195- 209.
} 


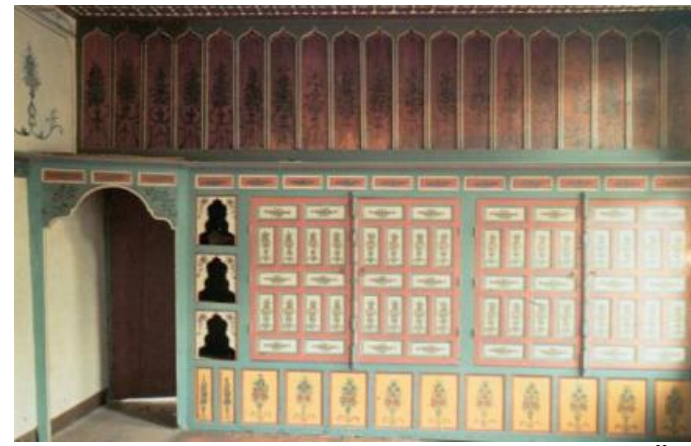

Figure 4. Çakırağa house of room and closet, Birgi, Ödemiş, İzmir

Traditional residences that can reach today, from small or large settlements of Anatolia, are a concrete reflection of the culture and life of the Anatolian family. The role of women /men in the family and the value judgments of the Islamic community have been an effective role in the scheme of the housing plan and the formation of their spaces. Outside is the male world, the house belongs to the woman. There were places needed for cooking, bread making, sewing, embroidery, laundry, fruit drying, woodcutting, animal breeding, which are included in the daily work of the woman. A barn was needed in the courtyard for donkeys, cows, horses, or mules. In addition to coops were needed in the courtyard or in the garden. All this created the common living conditions of an agricultural economy with rural characteristics. It can be said that the plan of the house develops according to the woman because she does daily work. The working areas of the woman in the home would open up to the courtyard. The entrance and ground floor was a controlled area that did not open outside much. The entrance o the house was like an impenetrable fortress gate.
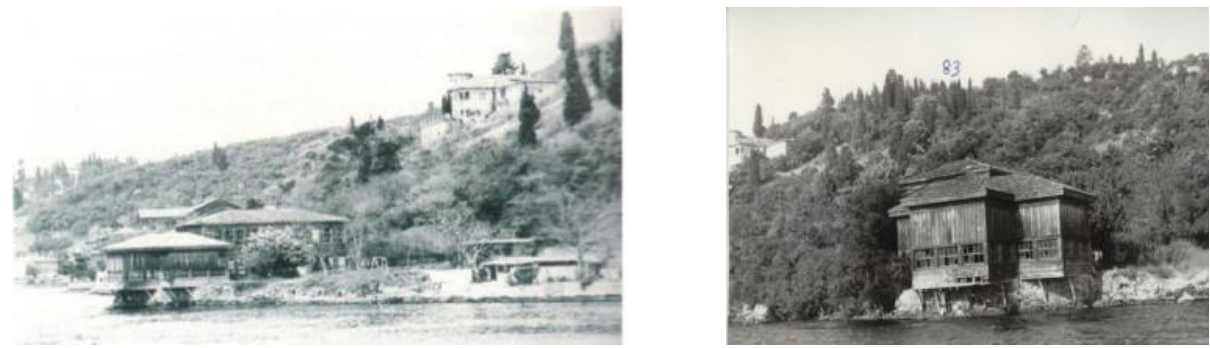

Volume 12

Issue 4

August

2020

Figure 5. Amcazade Hüseyin Paşa Waterside Residence, Figure 6. Amcazade Hüseyin Paşa Waterside Residence ${ }^{19}$

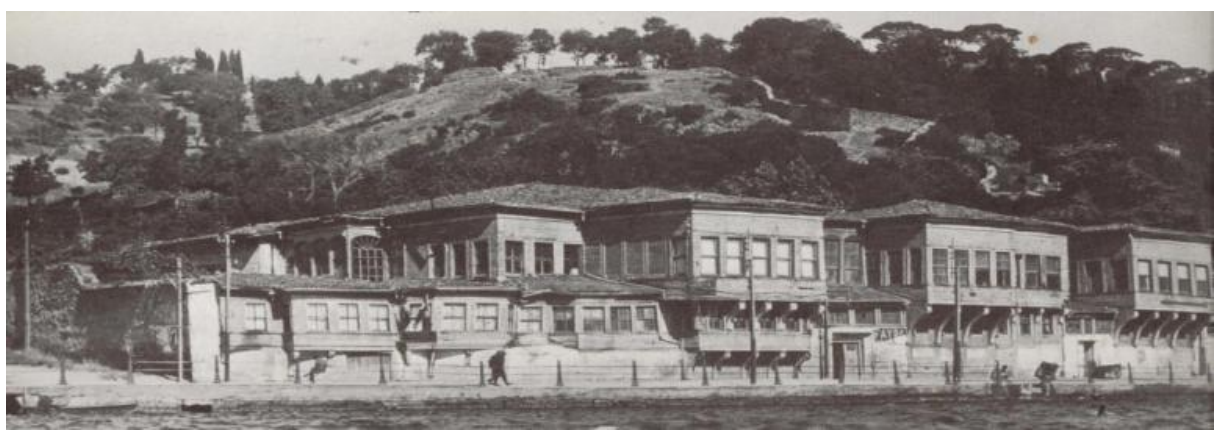

19 Özlem Atalan, "A Research on the Historical Changing Process of the Coastal Settlement of the Bosphorus and its Conservation Modals; Ortaköy-Kuruçeşme Coast", Phd Thesis, Yildiz University FBE, İstanbul 2008, s, 171. 
Figure 7. Muhsinzade Waterside Residence, ${ }^{20}$

The idea that the house was made for women does not write in the Islamic literature. But the social status of women is always emphasized. However, this status shaped the architectural features of the closed ground floors combined with the courtyard and the windows of the upper floors. The desire to see the street has been always attractive for those who live at home. From the 17th century onwards, it was accomplished in the planning of the Turkish house with the bay windows that opened out.

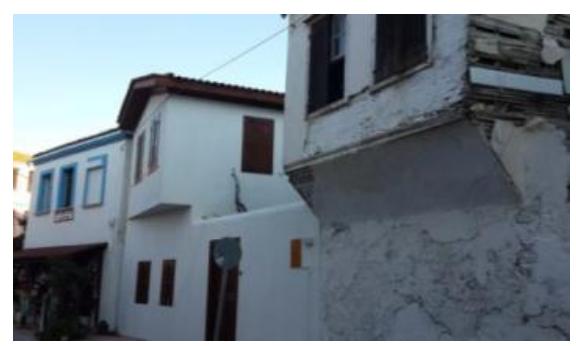

Figure 8. Çeşme Traditional Houses, Izmir

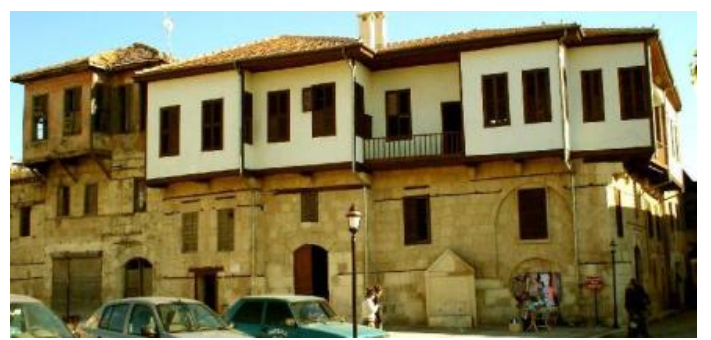

Figure 9. Traditional Tarsus Mersin Houses

\subsection{Hall and Room Connections in Traditional Anatolian Houses}

The Turkish house has been developed and sprawls for five hundred years. Due to climate, material, topographic and cultural effects, it has been seen in Anatolia and Balkans with different types. Despite this, it remained the same as outlines. According to Eldem, "Turkish House" has shown different regional developments. The traditional "Turkish house" consists of three main elements: the room, the iwan (the space between the rooms), the courtyard, the gallery opening to the garden or the hall (sofa). In this primitive scheme, the basic unit is the multifunctional room and the adjacent service area. The typologies of the Turkish house differ according to the different combinations of these elements.

Considering the construction technique, three materials were used in Anatolia, adobe, stone, and wood. Using these materials alone or in combination in different ways, this led to the emergence of Turkish house building types in different regions of Anatolia. As a result of the differences in the regional building traditions of Anatolia, we can say that there is no homogeneous building style in Anatolia. We see that Kuban divides, Anatolia into the following regions in terms of residential architecture ${ }^{21}$ :

- In the southeast Anatolian region, with the reflection of the shared culture with Northern Syria, stone house architecture is seen.

- Around Erzurum, there is a wooden bonded stone architecture connected with the South Caucasus and Dagestan of North East Anatolia.

- House architecture with a wooden skeleton is seen in the Eastern Black Sea region.

- Flat-roofed cubic stone architecture is seen in the Aegean and Mediterranean regions.

- In Central Anatolia, especially in Niğde and Kayseri (former Cappadocia) region, stone architecture related to Northern Syria is seen.

- In Central Anatolia, adobe architecture dating back to the New Stone Age, with more villages and small cities, is seen.

${ }^{20}$ Atalan, age, s, 171 .

${ }^{21}$ Kuban, age, s.50.

History Studies 
- The technique, which is seen between the coasts of the Anatolian coast and the central plateau areas, expanding from Sivas to the west and from the Inner Aegean to the north of the Taurus Mountains, and also seen in the Balkans, is a common construction technique. This skeleton structural system is wood. Adobe and stone materials were used as filling materials ${ }^{22}$.

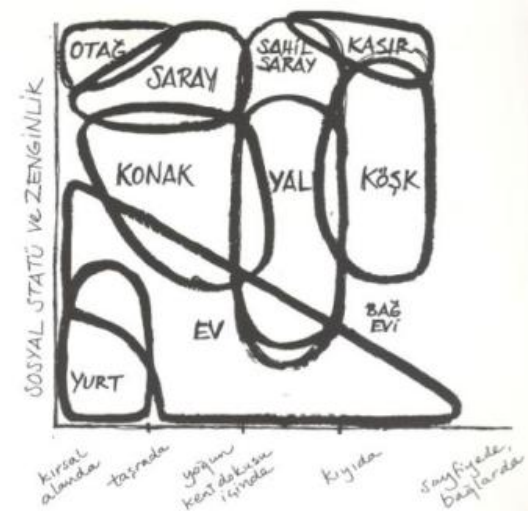

Figure 10. Words and concepts related to housing ${ }^{23}$

If we look at the "Turkish House" in terms of space organization, it can be said that two basic spaces constitute this connection. Rooms and hall are the mutual space for family. Hall is a shared area by family members. It can be closed, semi-closed or open. Hall section can be named as "Sofa, Sergah, sergi, seyvan, çardak, divanhane, hayat". Although hall section provides of family's circulation within the house, at the same time this area's function was space for user of gathering for some work.

Some sections which are out of circulation are reserved for sitting. Over time, some sections became more specialized for users and new spaces such as iwan, bench, throne, kiosk, and kiosk room were formed. Küçükerman, associates the formation of the room with the nomadic tent. He associated the formation of the hall with the circulation spaces between the nomadic tents ${ }^{24}$.
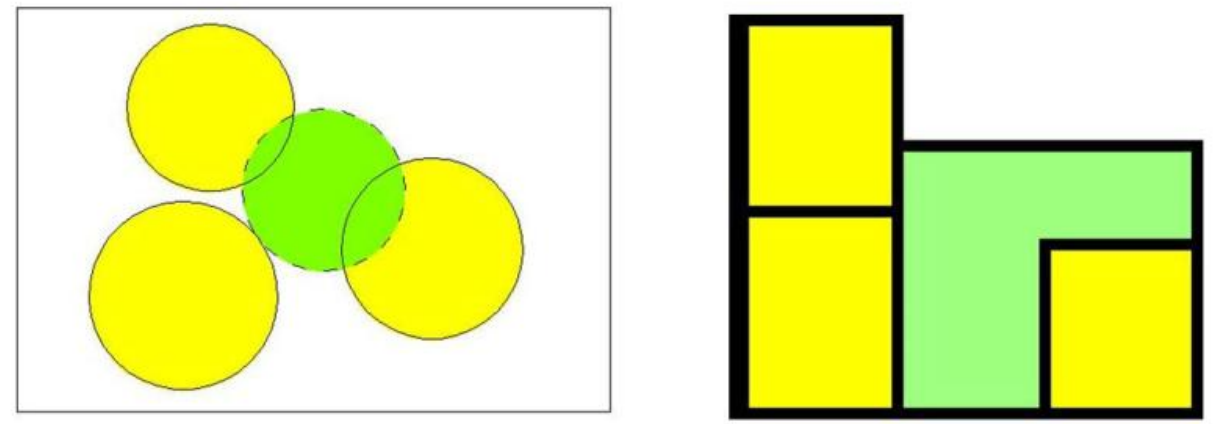

Figure 11. Transition from nomadic tent to traditional residence ${ }^{25}$

22 age, s. 50.

${ }^{23}$ Ahmet Turan Altıner- Cüneyt Budak, Konak Kitabı, Tepe Yayınları, İstanbul 1997.

${ }^{24}$ Küçükerman, age, s.59.

${ }^{25}$ age, s.66. It was redrawn by O. Atalan 


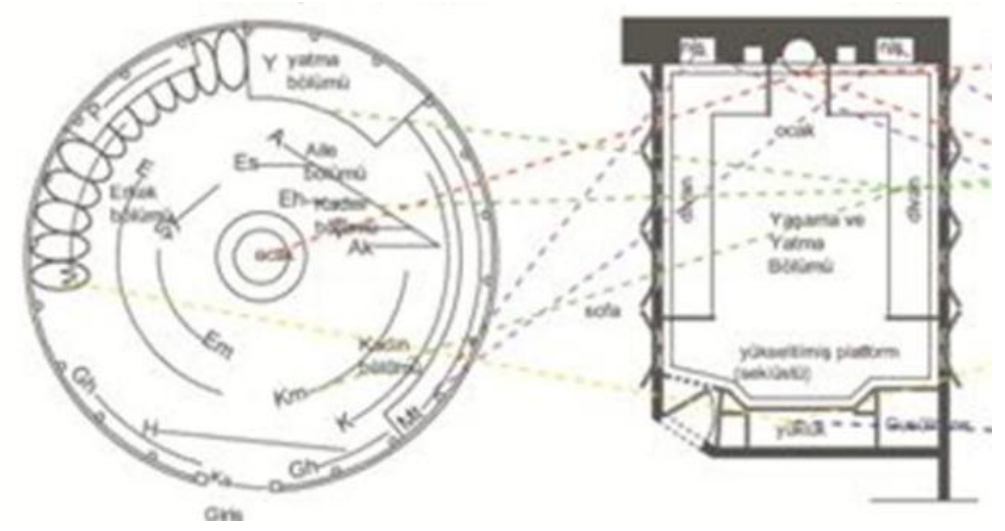

Figure 12. Connections of the nomadic tent and the Turkish room ${ }^{26}$.

A: Family, Y: Bed K: Woman Section H: Poor and Servants Location e: Man Section Şy: Place of Honour M: Leather Sacks O: Furnace, P: Place of Idol EM: Male Quest Es: Householder Eh: House of Wife Gh: Young Animal Ç. Children mt: Kitchen Housewares Ka: Door Ak: Relatives Km: Female Quest.

Volume 12

Issue 4

August

2020

In the Muslim Anatolian family, especially after the 18th century, women's place in the society and her working area in house became combined. Since the man is less being in the house, the house is planned according to the life of the woman. In this period, especially bread baking, sewing, laundry, cloth or carpet weaving, fruit drying, "tarhana" etc. preparation, wood cutting, feeding animals, milking, etc. activities were done by woman. In Kuban it is stated that the nomadic woman also carried out similar activities in and at the tent ${ }^{27}$.

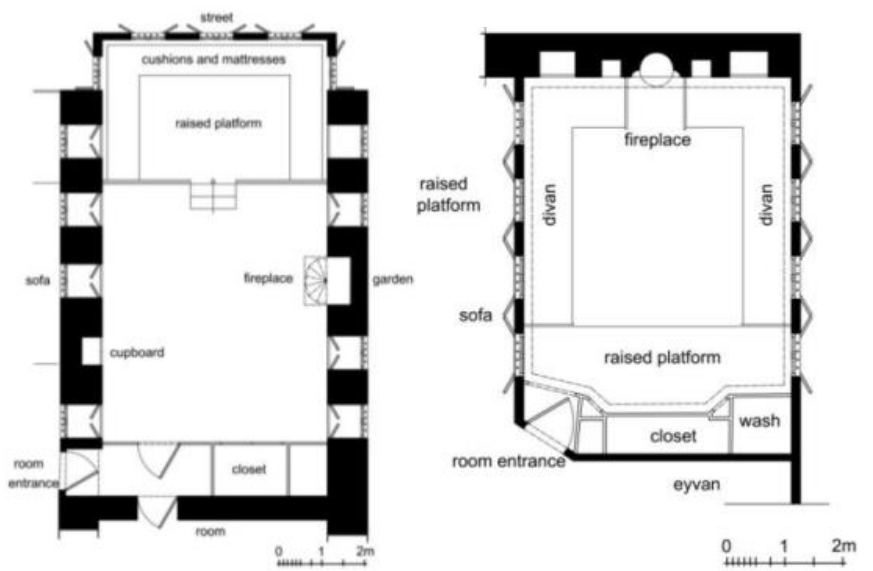

Figure.13 Traditional Room, Safranbolu ${ }^{28}$

The main determining parts of the traditional plan are sometimes divided into halls and rooms, sometimes as interior hall and central hall, and sometimes as rooms, iwans and halls. The connections between these sections are associated with the inner and outer of the tent life. Köse underlines the connection between the meanings and function of the hall unit in the traditional housing plan and the iron pile or iron tree (tree of life) which in front of the nomadic

\footnotetext{
${ }^{26}$ Özlem Atalan - Elif Süyük Makaklı, Türklerde Yaşama Kültürünün Değişimi; Tek Mekân Göçebe Çadırından, Minimalist Dairelere Geçiş, Sosyo-Economık Stratejiler 4: Tasarım Stratejileri, Publisher: Ijopec, 2018 Londra.

${ }^{27}$ Kuban, age, 2007, s. 83.

${ }^{28}$ Küçükerman, age, s.115. It was redrawn by O. Atalan
}

\section{History Studies}


tent ${ }^{29}$. The nomadic family would go from the hot weather in summer seasons to the coolness of the mountains and plateaus. In winter seasons, they migrated to warm regions. This action is corresponded to the family's living in the traditional residence moving to winter seasons from upper floors to middle floors or warm rooms. In summer, the family is moved to cooler rooms, hall or courtyard on the contrary ${ }^{30}$.

Although it is generally accepted that the traditional room was the main component of the Ottoman House and this view is supported by various scientists. But, the sight of mophogenetic connection with the nomadic tent is a controversial subject for some scientist. While Küçükerman and Kuban underlined this connection, Tanyeli stated that the connection to the traditional room with the tent is considered shortcut and direct association ${ }^{31} 3233$.

We can say that the classical period of the Turkish House with hall is roughly 18th century. Çakırağa Mansion (Odemis- Izmir) is one of the important structures of Turkish residential architecture built in this classical period. A U-shaped plan scheme was used for increase of the number of rooms which were lined on the sides of the hall. In Çakırağa Mansion, some architectural elements of classical period such as throne or kiosk have been transformed to the kiosk rooms. In addition, a small kiosk detail can be seen in the middle of life. In addition to the main iwan, small iwans took place in the spaces between the rooms. The U-shaped plan became an example for the development of axial and central plan types in later periods. Asymmetrically placed, three-roomed houses are the most common types in the 19th century. We can see that similar house plans were built simultaneously, starting in the late 17th century. The classic plan Turkish house continued to be built in Anatolia until World War $2^{34}$.

A number of traditional residential structures that best describe these developments are located in Kula- Manisa. The Beyler House, dating from the 18th century, is a good example of classical design. There is a ground floor with little connection with the street. The rooms on the first floor open to the hall. The kiosk section of the house has been converted into a room. These rich interior spaces, which are formed around a bright, airy and lively hall, provide a great living comfort during the summer seasons.
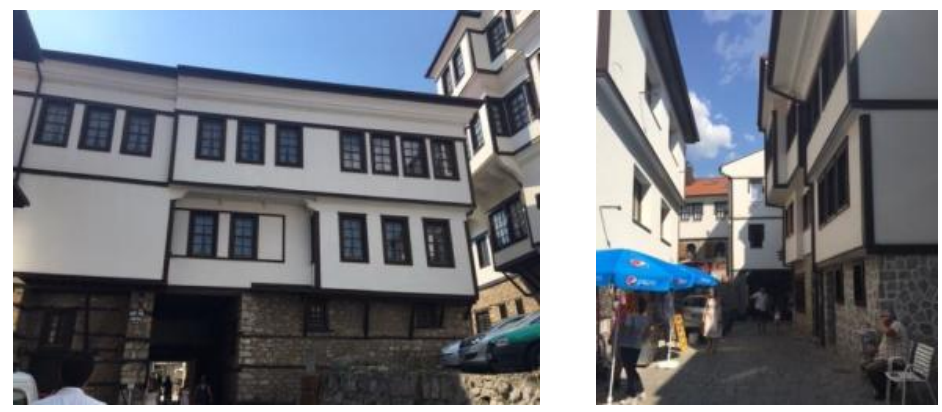

Figure 14. Traditional Turkish Houses in Ohrid North, Macedonia

Figure 15. Traditional Turkish Houses in Ohrid North, Macedonia

Volume 12

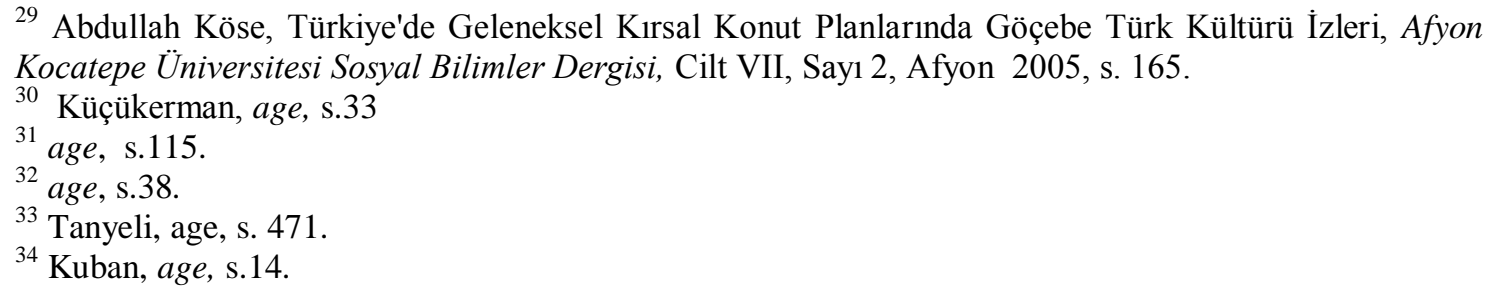


In aristocratic dwellings, the use of a central plan has a rather old history in Islamic architecture, beginning with the "narrow-al-imra" of early Muslim cities. We see the continuity of this tradition, in the history of Ottoman palace architecture. According to Kuban, even though the centrality has an inherent monumental feature for the dwellings of the nobility, monumentality has never been a desire in the Turkish public residences. Starting from 18th and 19th centuries with the influence of palace design technique and western architectural movements, introverted, symmetrical or central typologies have developed in all Anatolian city houses ${ }^{35}$.

As a result of the transformation of the house, the semi-rural characteristic of architectural features had disappeared. Houses were started to be built on smaller plots and at the street in the rows. The shrinking courtyards were behind the house. The shape and layout of the rooms with iwans were close to the old dimensions. The iwan, which were one of the important elements of the classical Turkish house, had either disappeared or turned into rooms. In this process, the entrances of traditional houses were begun to open directly inside of the house. The floor that the owner of the house uses for living was still the first floor. In some houses, the low ceiling mezzanine floor, which is used as a winter room by women, were reached by stairs.

The trend of centralization in house plan schemes continued in this process. The corners of the hall were designed by cutting the middle area into an octagonal shape. The plan type, which developed in the late 18th or 19th century cities, can be divided into two. The first is the inner hall (karniyarık) plan consisted of rooms on both sides. The second is the central hall scheme, which consists of corner rooms around the hall (Cruciform).

\section{1 \\ Volume 12

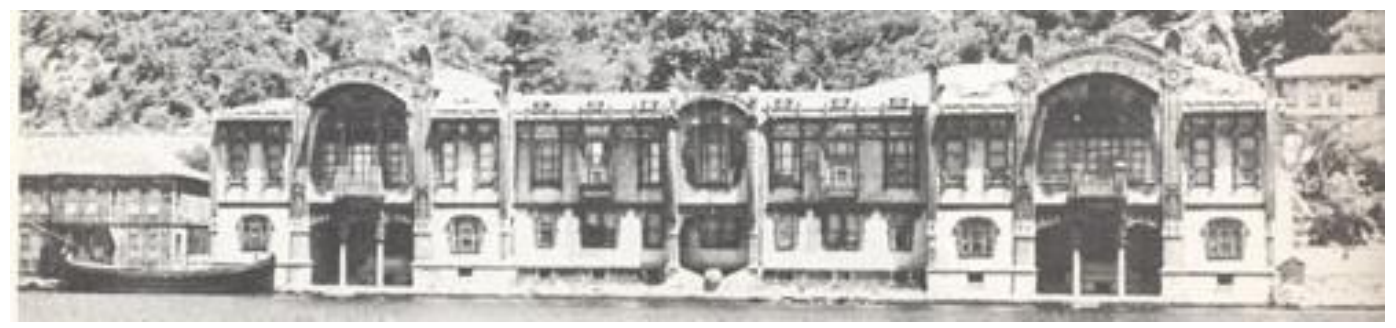

Figure 16. Nazime Sultan Water Residences ${ }^{36}$

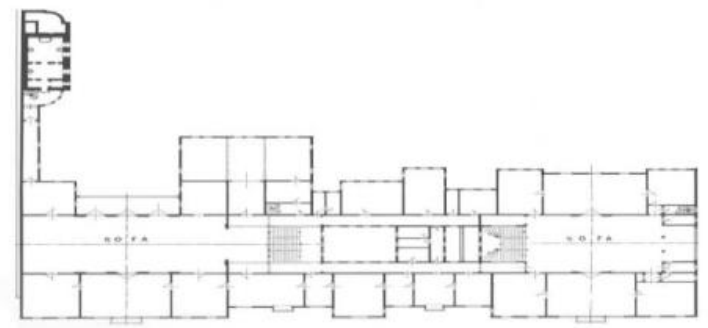

Figure 17. Nazime Sultan Water Residences ${ }^{37}$

The cruciform (cross-shaped) central hall is close to the Turkish architecture. However, the reason we often see it in 19th century architecture can be attributed to the influence of

\footnotetext{
${ }^{35}$ Kuban, age s.35.

36 Özlem Atalan, "A Research on the Historical Changing Process of the Coastal Settlement of the Bosphorus and its Conservation Modals; Ortaköy-Kuruçeşme Coast”, Phd Thesis, Yildiz University FBE, İstanbul 2008, s,171.

37 Atalan, age, s. 21.
} 
European Neo-classicism. This symbolic and spatial plan was used generally in the house of wealthy families. In the type called "Karniyarik", it had been widely applied in Istanbul. In the houses with separate harem, the building section consisting of two rooms and a hall (sofa) had been expanded by adding to the first plan of "Karniyarı""38

In small towns and in regions with a mild climate, the houses seen are generally with external hall. In the houses with external hall, the rooms are usually around 15-20 square meters. The floor section entered into the room is named as "sekialtı". This section is one more step below the sitting section. The rooms have different sections according to their functions. It is seen that the rooms are used for activities such as sitting, eating, lying and washing. The divan used to sit and built with the building is located inside the room. Generally, there is a stove on the wall opposite the entrance door. In addition to the stove, the "gusulhane" (space for ablution and washing function), cupboard, niches are other elements in the rooms. Kitchen and toilets are located in the courtyard. Some of the kitchen house wares are located in the niche sections on the top and sides of the furnace. We can state that the principles of establishing of the rooms and their functions in the structure as follows:

- The room is a piece of space built for the vital actions and needs of family.

- The interior arrangements of the room are designed with certain social and cultural principles. Hall and courtyard spaces are planned as the common usage area of the family ${ }^{39}$.

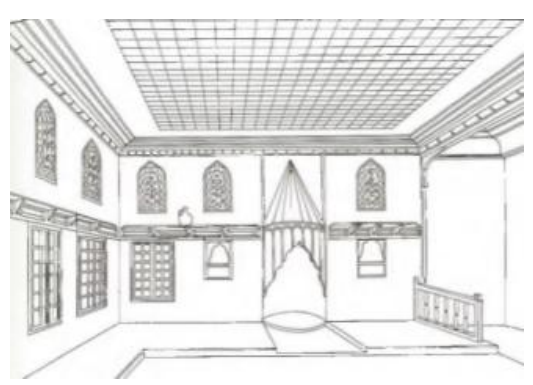

Figure 18. A room perspective drawing ${ }^{40}$

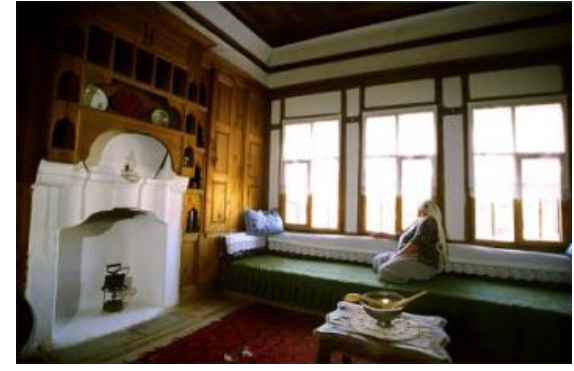

Figure 19. Traditional room, Rize- Çayeli

\subsection{Traditional House and Plan Types}

The origins of the plan type of without a hall and an external hall housing plan have been associated with the ancient Anatolian and Middle Eastern housing. Without a hall plan types is seen the most primitive type ${ }^{41}$. The traditional residence had one room without a hall plan types, had changed as a plan with an external sofa in the following period. Over time, plan types with external, inner and central hall had emerged. Hall, although was a circulation area. It is a place where households gather in with a iwan and a kiosk spaces. Sometimes, one or two sides of the hall are added to the bench, which is raised by steps ${ }^{42}$.

The hall where the family members are, shares life with daily tasks such as sitting, cooking and meeting. It has been used extensively, especially to take advantage of the coolness in summer. While the room was the private area of the woman and her family, the sofa was

\footnotetext{
${ }^{38}$ Kuban, age, s. 41.

${ }^{39}$ Küçükerman, age, s.73.

${ }^{40}$ Reha Günay, Türk Ev Geleneği ve Safranbolu Evleri, Yem Yayınları, İstanbul 1998, s.50.

${ }^{41}$ Eldem, age, s. 14.

${ }^{42}$ Küçükerman, age, s. 109.
} 
considered as a general area ${ }^{43}$. According to Bammer, the traditional European house does not offer a space quality as specialized as the Turkish house ${ }^{44}$. The Anatolian traditional house is a combination of spaces that have been designed and planned. Especially in multi-roomed structures where the family lives in the crowd, the usage capacity of rooms had been high. In the hall area, the woman sits with her family and children. Sometimes she does seasonal work in this wide area. Many things are done by women in the hall, such as making and drying "tarhana" (dried soup ingredient), cutting pasta, drying various vegetables and fruits, and weaving carpets. With the furnace placed in one corner of the hall, this place is also used as a cooking place. In good weather, the hall section (and / or courtyard) becomes a dining place. With this arrangement, the interior is protected from smoke and food odors. It is seen that in some hall spaces, there is a raised kiosk space and stairs for a vertical circulation. The "iwan" located in the hall is a section that is used according to the wishes of the people living at home.

The plans of the traditional Turkish houses are grouped according to the shapes and the locations of their halls within the plan. Eldem, classified the plan types into four groups ${ }^{45}$ :

- Without a hall;

- With an outer (External) hall;

- With an inner hall;

- With a central hal

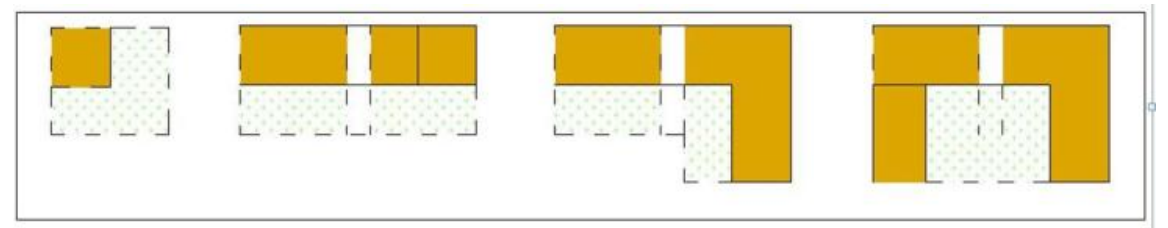

Figure 20. Without a hall plan types ${ }^{46}$.

This type of plan is generally seen in hot regions of Anatolia in Turkey. Among the rooms, there is a multi-purpose external space used by family members.

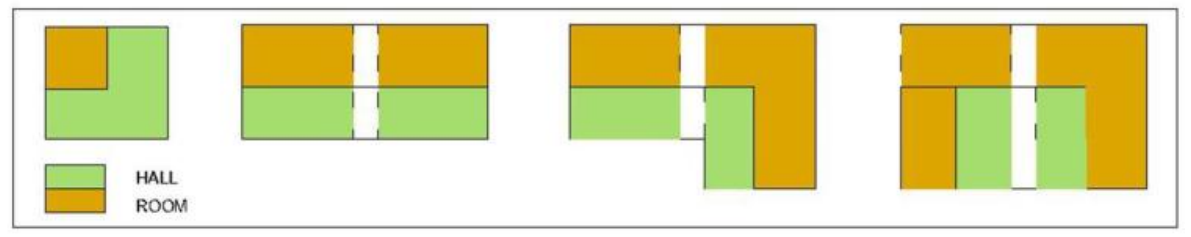

Figure 21. External Hall Plan Types ${ }^{47}$

It was built mostly in warm and temperate areas of Anatolia in Turkey. Family members provide circulation between rooms with this covered space.

\footnotetext{
${ }^{43}$ Murat Kazmaoğlu-Uğur Tanyeli, Anadolu Konut Mimarisinde Bölgesel Farklıllklar, Yapı: 33, İstanbul 1979/13, s.29-41.

${ }^{44}$ Anton Bammer, Çadır ile Anadolu Evi İlişkileri, İstanbul Habitat 2, Tarihten Günümüze Anadolu'da Konut ve Yerleşme, Türkiye Ekonomik ve Toplumsal Tarih Vakfi, Ofset Yayınevi, 1996 İstanbul, s.243.

${ }^{45}$ Eldem, age, s. 14.

${ }^{46}$ Küçükerman, age, s.66. It was redrawn by O. Atalan.

${ }^{47}$ age, s.102. It was redrawn by O. Atalan.
} 


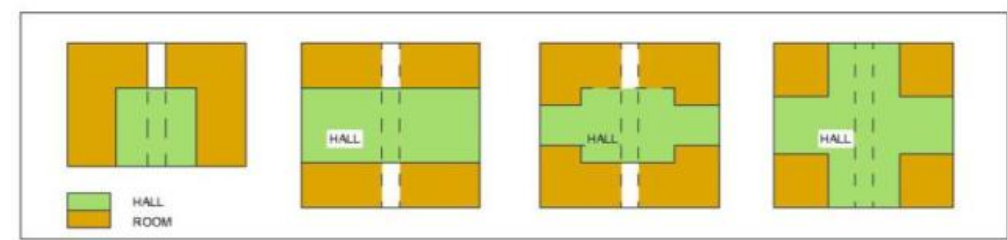

Figure 22. Interior Hall Plan Types ${ }^{48}$

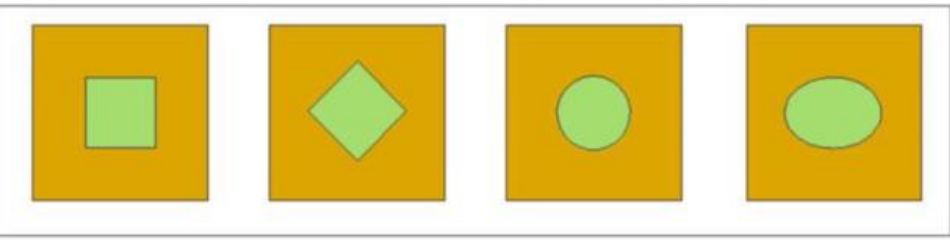

Figure 23. Central Hall Plan Types ${ }^{49}$

Table 1. Traditional Turkish House Plan Types ${ }^{50}$.

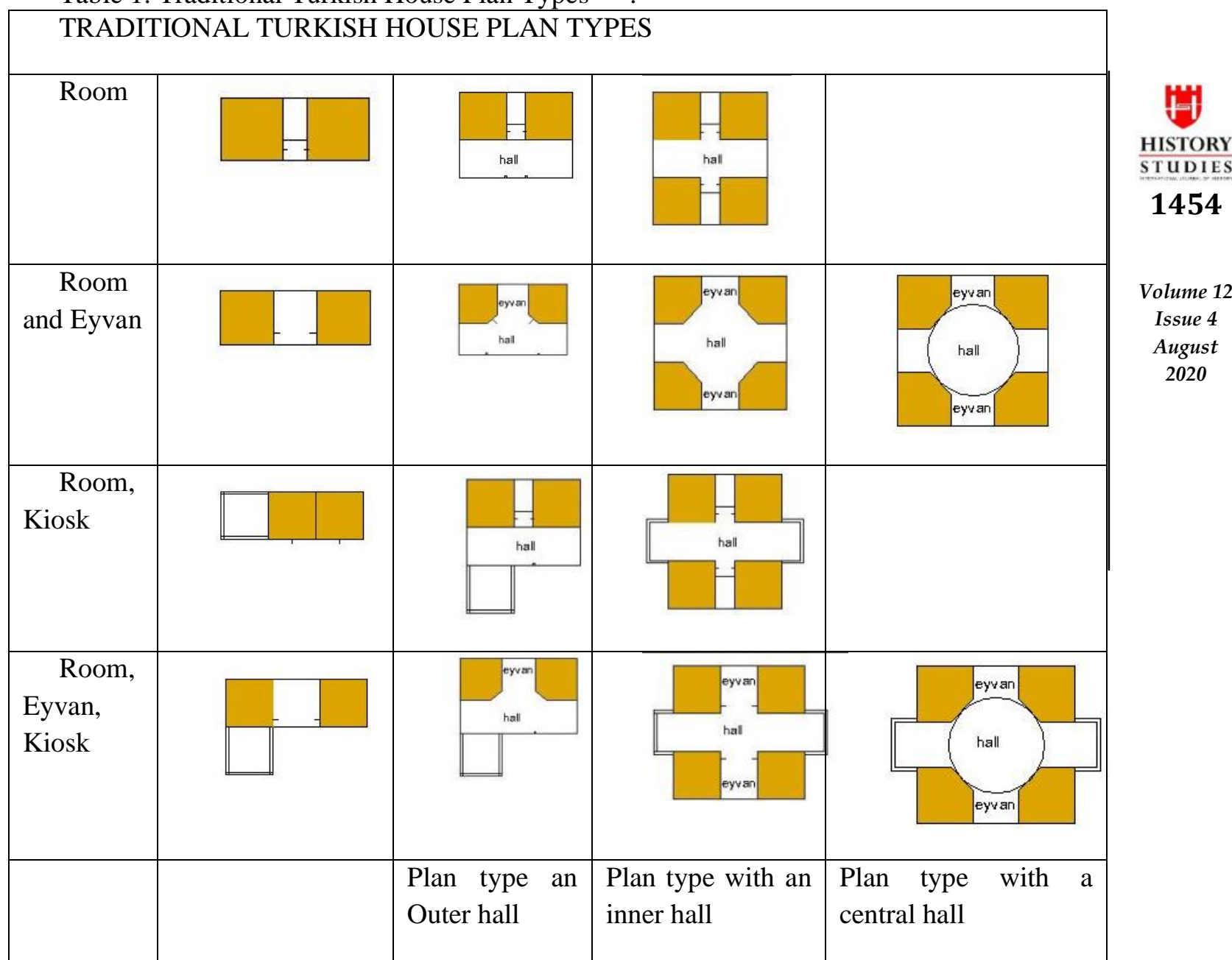

${ }^{48}$ age, s.103. It was redrawn by $\mathrm{O}$. Atalan.

${ }^{49}$ age, s.103. It was redrawn by $\mathrm{O}$. Atalan.

${ }^{50}$ Eldem, age, s. 14. It was redrawn by O. Atalan. 


\section{General Features of Traditional Kula Houses Room- Sofa Section Connections}

The characteristics of the Turkish Houses and their architectural features are repeated in Kula Houses. The ground floors are introverted and irregular planned because of the irregular parcels and streets. The upper floors are associated with the external environment visually through many windows. Wide eaves and curvilinear surfaces are the characteristics of Kula Houses. In traditional Kula houses often have two, sometimes three floors. The courtyard is usually located at the front or back of the houses. The courtyard is surrounded by a high stone wall. In early examples, traditional families enter the courtyard through the stone wall. In the late period, they first enter the building and then pass into the courtyard. In the second half of the 19th century, interior and central hall plan types are seen. The houses planned in these schemes have two doors: street door and courtyard gate. The courtyards of the buildings are covered with flagstone. The courtyard walls of the buildings were built with slate.
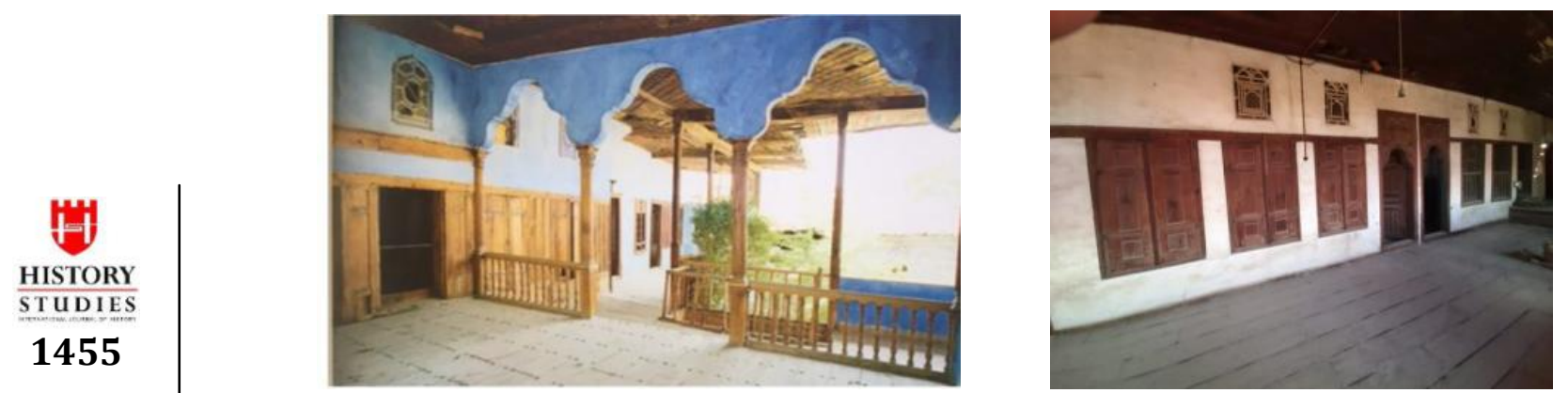

Volume 12

Issue 4

August

2020

Figure 24. view of the hall in Kula Houses Figure 25. view of the hall in Kula Houses

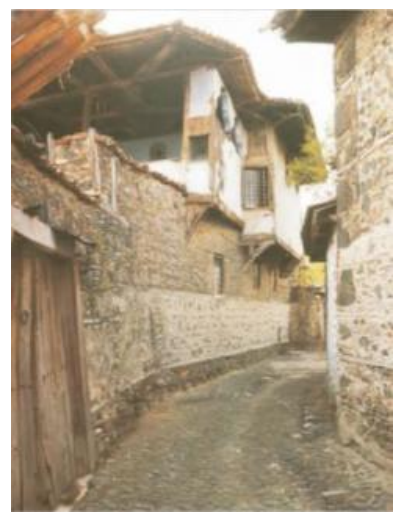

Figure 26. Kula Streets , $1994^{51}$

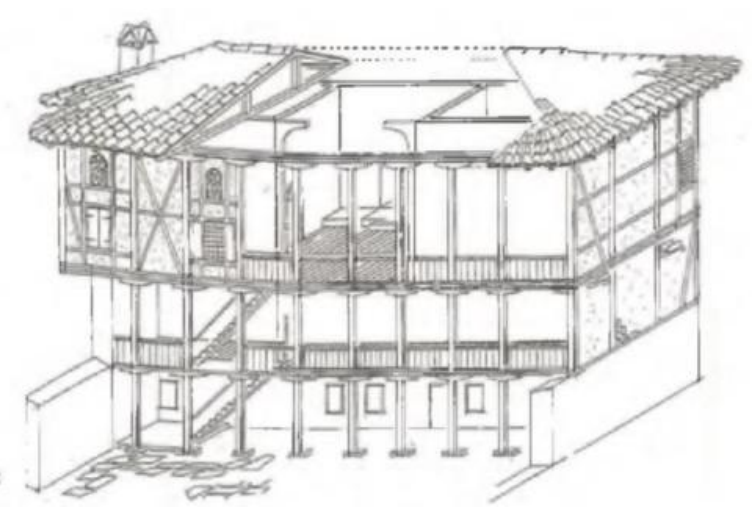

Figure 27. Kula Streets ${ }^{52}$

Kula traditional residences, which are examined in detail by Bozer ${ }^{53}$, Tosun ${ }^{54}$, Eldem ${ }^{55}$, Akın and et al ${ }^{56}$ are quite remarkable with their hall and room plans, and the majority of the buildings are very large. In Kula's traditional residences, there are many functional service

\footnotetext{
${ }^{51}$ Kuban, age, s.57.

${ }^{52}$ Kuban, age, s. 57

${ }^{53}$ Rüstem Bozer, Kula Evleri, Kültür Bakanlığı Yayınları, Ankara 1988, s.10.

${ }^{54}$ Yılmaz Tosun, "Milli Mimarimizde Kula Evleri”, Ticaret Matbaacılık T.A.Ş.,İzmir 1969, s. 16.

${ }^{55}$ Eldem, age, s. 14.

${ }^{56}$ Akin Nur- Zeren Nuran- et al, Conservation Aimed Development Plan Report of Kula, Manisa, 1994.
} 
places on the ground floor of the building. These are a kitchen, toilet, barn, cellar, storage, furnace, etc. On the upper floors, there are rooms, sofa, and sometimes kiosk and iwan sections. There are wooden pillars or stone columns under the hall. In some homes have mezzanine floors. Kula traditional houses are generally built in wooden carcass masonry architecture. The ground floors of the houses built as masonry stones, the upper floors of the houses are made of mudbrick or stone material filling between timber carcasses. Some of the buildings were built entirely as masonry construction system. Generally stone-masonry structures have reached today in better condition than timber carcasses building. Local people used the stone material from the volcanic area near Kula. They used "Karataş" (Black Stone) and Kufeke move on their courtyard walls and slate stone on ground floor.

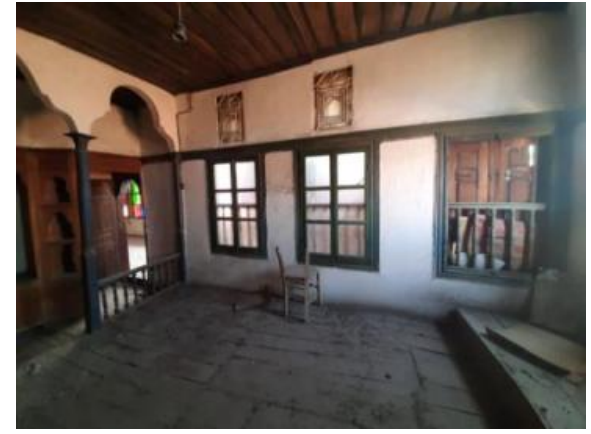

Figure 28. A view from the Traditional Kula House room Traditional Kula House hall

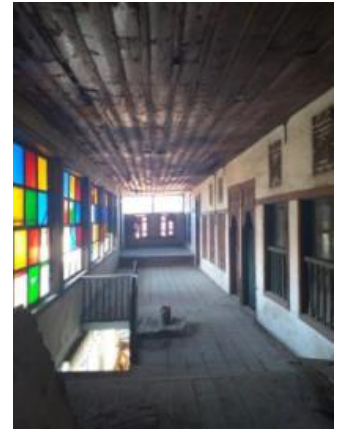

Figure 29. A view from the
HISTORY

STUDIES

1456

Volume 12

Issue 4

August

2020

Figure 30. Hall and Room Arrangements of Kula Houses ${ }^{57}$.

We see that frequently built in external hall plan types of the Kula houses. There are also intern and central plan types. We see houses with external hall schemes of single-room, tworoom or multi-room with kiosk and iwan. These are separated in itself, according to geometry and position of the hall and house plan. Besides, the sub-types that are named according to the hall are enriched of iwan, kiosk and kiosk room. According to Akın, traditional Kula houses separated for 4 groups for type of hall. These are straight hall, $\mathrm{L}$ formed hall, corner hall, $\mathrm{U}$

57 Esra Kurtaş, Evaluation of Architectural Heritage Characteristics of Bekirbeyler House In Kula, Manisa, Thesis Submitted to The Graduate School of Engineering and Sciences of Izmir Institute of Technology In Partial Fulfilment of The Requirements for the Degree of Master of Science in Architectural Restoration, 2013 İzmir, s.45. It was redrawn by O. Atalan. 
formed hall ${ }^{58}$. According to the work of Akin, most of the residences in the Kula urban site have straight and open hall plans. 283 out of 302 buildings have an open and straight hall plan. 22 of them are seen in a traditional building with an iwan scheme. Kiosk sections are attached to 52 building of hall. 6 of them are attached with iwan and kiosk or kiosk room. Selected of the 302 structures, 2 of them are the L-types, 13 of them are corner-types and 4 of them are Ushaped hall plan types ${ }^{59}$.

Table 2. Kula Traditional Houses Exterior Hall Plan types ${ }^{60}$

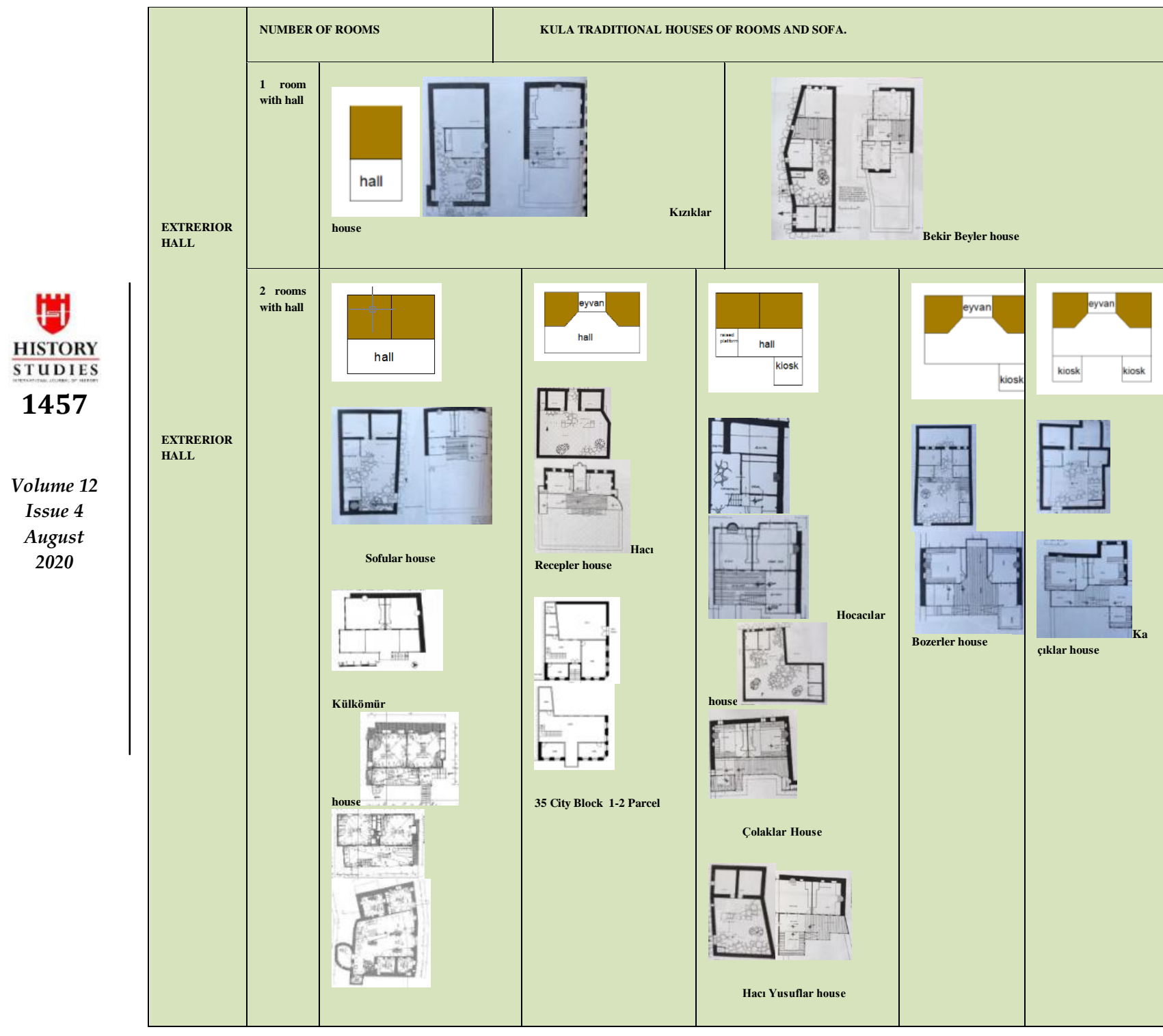

${ }^{58}$ Akın, age, s. 10 .

59 age, s. 10 .

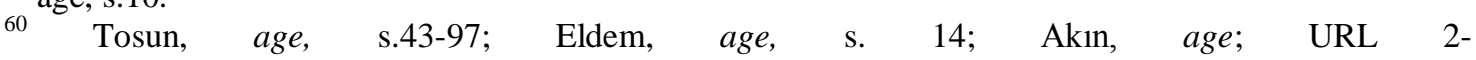
http://www.admimofis.com/ProjectDetails.aspx?pID=MP8Rnp3rOWM\%3D; Eti Akyüz - Deniz Orhun, Bilge Yıldırım, Özlem Arıtan,, Kuladan iki ev, Ege Mimarlık, sayı. 33, 2000 İzmir; Surveys are redrawn as schematic plan by Atalan. 
Learning from Hall and Room Arrangements; Examples from Kula -Manisa Traditional Houses

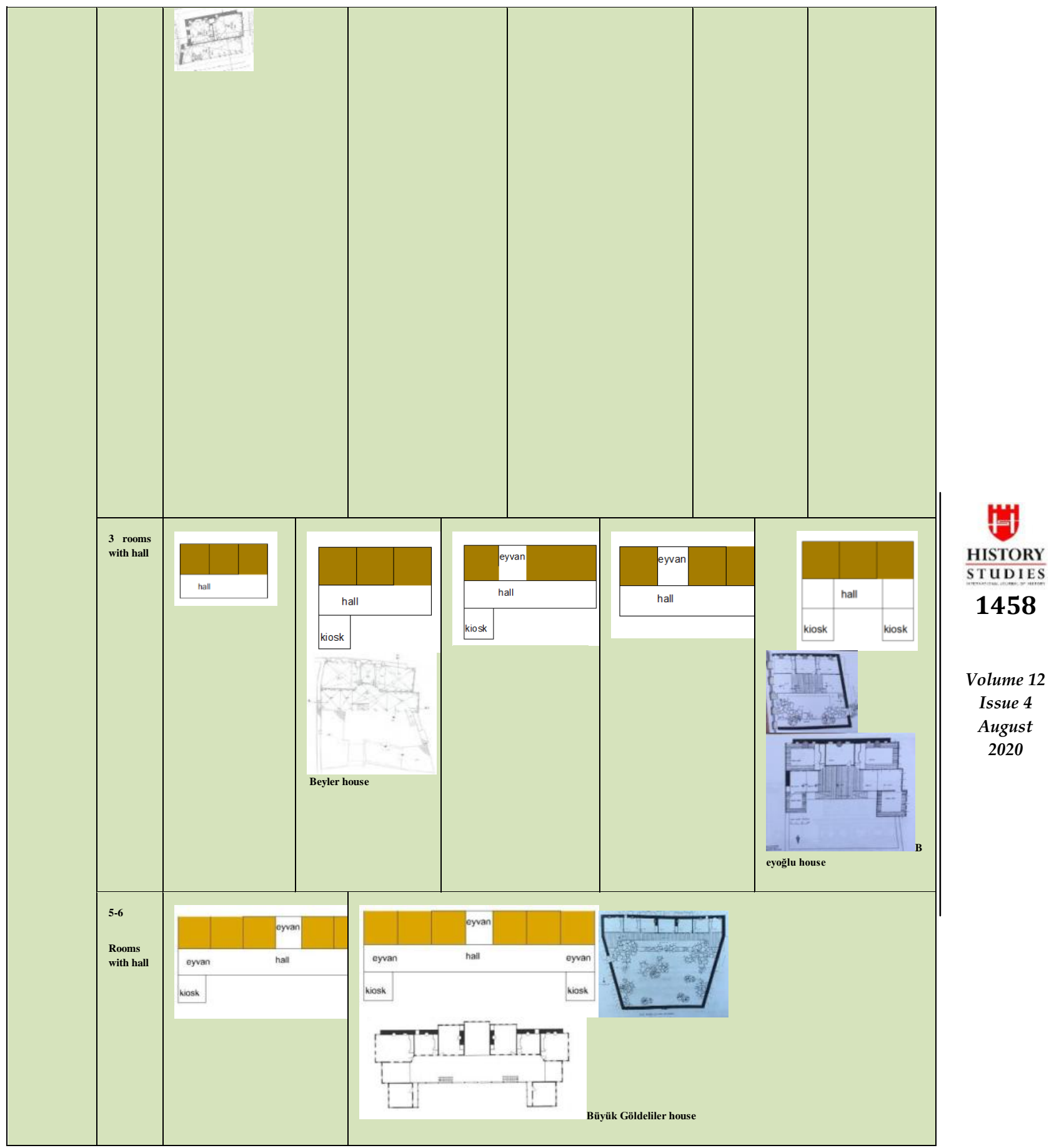




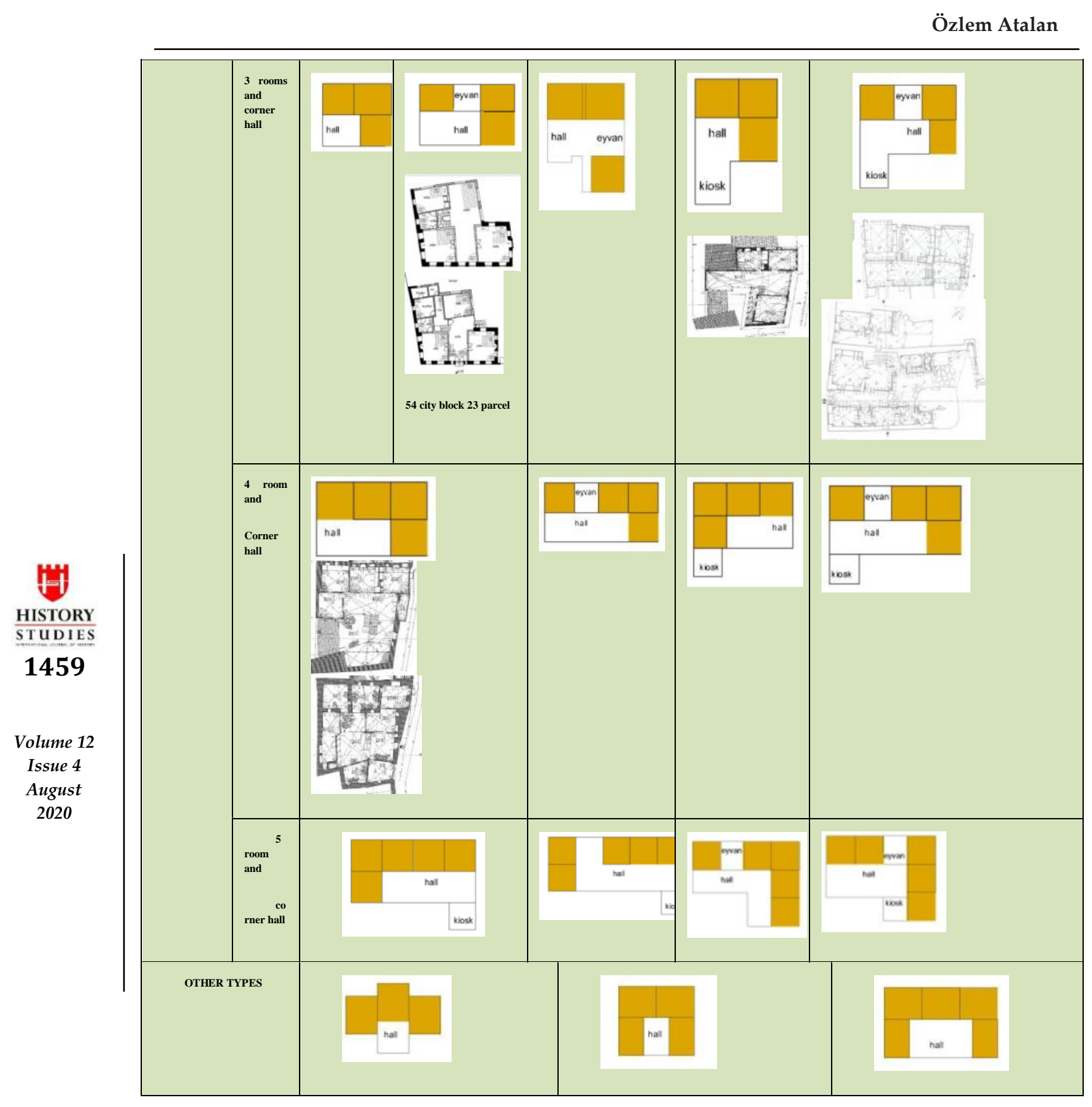

A total of 25 houses were examined in Kula Urban Site. 2 of these houses are with 1 room, 1 of these houses with 1 room with kiosk (Kizıklar- Bekir Beyler House). 16 of them have a straight hall plan. 4 buildings have 2 rooms and straight hall plan. 2 of them have 2-room with an iwan (Hac1 Recepler House-35 City Block 1-2 Parcel) . 3 of them have 2 rooms with kiosk plan (Çolaklar- Hacı Yusuf- Hocacılar House). One of them has 2 rooms with iwan and kiosk (Bozerler House). One of them has 2 rooms with iwan and 2 kiosk (Kaciklar House). One of them has 6 rooms- 2 kiosks with straight hall plan (Büyük Göldeliler House). 
Tablo 3. Kula Traditional Houses inner and central hall plan types, ${ }^{61}$

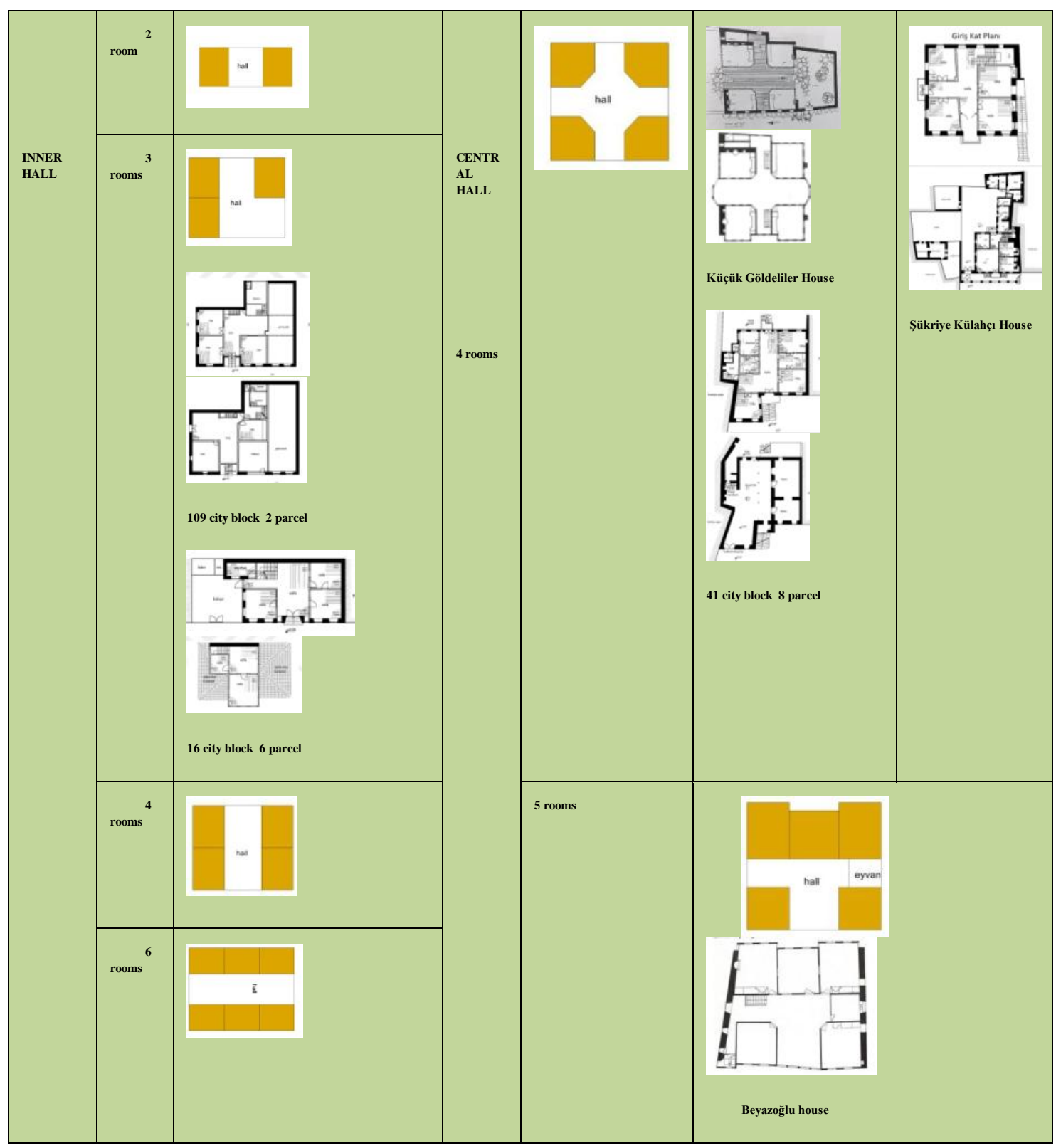

Volume 12

Issue 4

August

2020

One of them has 3 rooms with 1 kiosks (Beyler House) One of them (Beyoğlu House) has 3 rooms with 2 kiosks. 3 of them have 3 rooms with a corner hall. 1 of them has 4 rooms with a

61 Bozer, age, s. 10-35; Eldem, age, s. 14; Akın, age, s.10; URL 2http://www.admimofis.com/ProjectDetails.aspx?pID=MP8Rnp3rOWM\%3D; Emine Derin, Manisa İli Kula İlçesindeki Sakız Tipi Evler Ve Koruma Sorunları Üzerine Bir Araştırma, Yüksek Lisans Tezi, İstanbul 2019, s. 128-206; Esra Kırtaş, Evaluation Of Architectural Heritage Characteristics Of Bekirbeyler House In Kula, Manisa, Thesis Submitted To The Graduate School Of Engineering And Sciences Of Izmir Institute Of Technology In Partial Fulfilment Of The Requirements For The Degree Of Master Of Science In Architectural Restoration, İzmir 2013; Surveys are redrawn as schematic plan by Atalan. 
corner hall plan. 2 of them has 3 rooms with inner hall plan. 3 of them has 4 rooms, one of them has 5 rooms with a central hall plan (Küçük Göldeliler House, Beyazoğlu House).

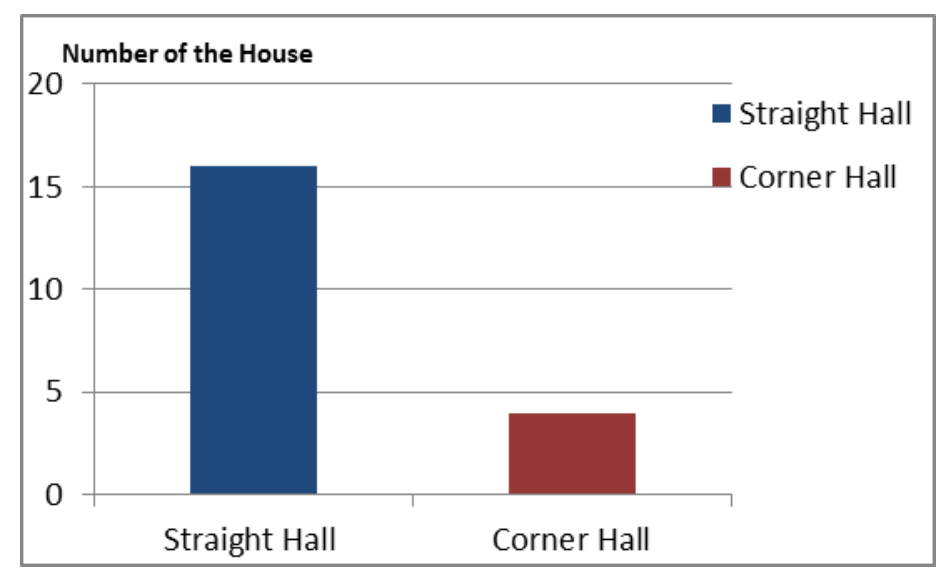

Figure 31. With External Hall Plan Types of the Kula Houses

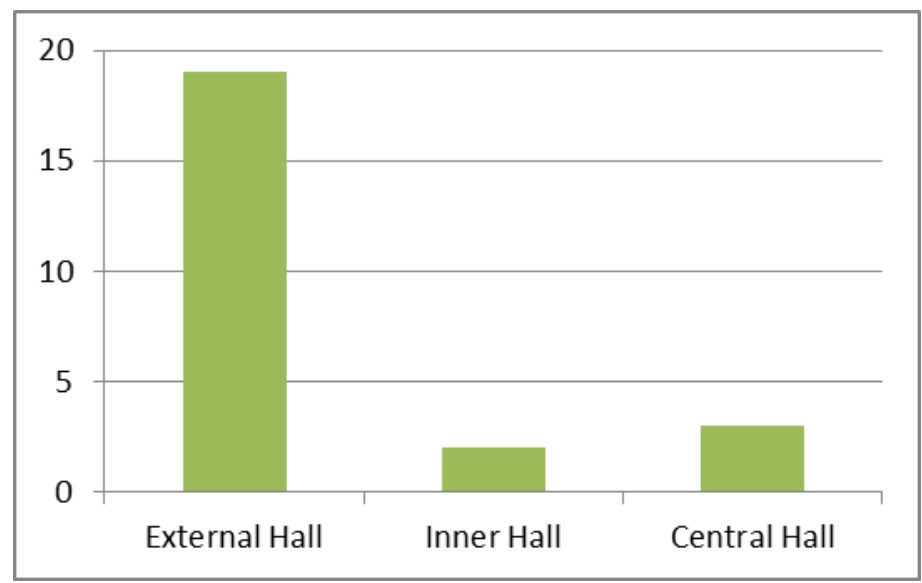

Figure 32. With External- Inner- Central Hall Plan Types of the Kula House

It is seen that 25 of the traditional buildings, 19 of them have outer hall. 2 of the 25 traditional buildings were built with an inner hall plan. 4 of the 25 traditional buildings were built with a central hall plan.

\section{Conclusion}

To ensure the sustainability of historical environments, the local identity of the settlements should be preserved. Even today, it is suggested to be featured frequently due to globalization and change pressures. Preventing the historical circles from disappearing under the pressure of intense change can be possible by protecting the architectural elements of the building. Supporting architectural elements and the use of local materials in newly developing urban planning will contribute to the continuity and sustainability of the historical urban identity.

The traditional houses within the Kula Urban Site are an indication of the creativity of the Anatolian society with their admirable looks and architectural elements. These historical environments need to be protected and maintained. In Kula traditional residences, it will be a study that identifies and emphasizes materials and details, protects the identity of the region 
and supports the maintenance of the historical environment. The use of local elements and building materials from the region should be ensured in both new architectural structures and historical restoration practices to be built in Kula. The repetition of historical urban elements and highlighting the characteristic features of historical environments will emphasize the difference of the region from other cities.

The family, living in the traditional houses of Kula, shows the culture of living both inward and outwardly with its plan with an outer hall and courtyard. These houses with external sofas and gardens meet all the needs of large families living between 18th and 20th centuries. Circulation connections between sofa space and room spaces in traditional houses are related to the lifestyle of the historical period. Within the scope of the study, 4 types of sofa-room connections were determined in houses with external sofas. Traditional Kula houses ( with outer hall) separated for 4 groups for type of hall. These are straight hall, $\mathrm{L}$ formed hall, corner hall, $\mathrm{U}$ formed hall

A total of 25 houses were examined in Kula Urban Site. 2 of these houses are with 1 room, 1 of these houses with 1 room with kiosk. 16 of them have a straight hall plan. 4 buildings have 2 rooms and straight hall plan. 2 of them have 2-room with an iwan. 3 of them have 2 rooms with kiosk plan. One of them has 2 rooms with iwan and kiosk.One of them has 2 rooms with iwan and 2 kiosk. One of them has 6 rooms- 2 kiosks with straight hall plan. Within the scope of the study, 20 of the 25 examined houses have an outer sofa plan. It is seen that the vast majority of the urban conservation area was built with an external sofa. In addition, the structures were generally built with straight sofas. In cases where the parcel area is limited, it has been built as corner hall plan type in buildings. It is seen that the buildings with inner or central halls are built in the Kula Urban protected area. The courtyards of the houses, which have inner hall or central hall are located at the back. In the houses with external hall, it is generally passed to the courtyard and then to the building. In the houses with open sofas belonging to the late period, it is seen that the building was first entered and the courtyard was passed from there.

The most striking plan element that highlights Kula differently from other Anatolian residences is its outer halls and rooms. In addition to the historical and cultural values of Kula, it is important to examine the traditional architectural design and building materials with exterior hall that form the local character in terms of maintaining the urban aesthetics and identity. It has been used for centuries, and has a sustainable design approach and building materials; the type of plan with outer hall has ensured a lifestyle that is compatible with the local climate and lifestyle of the historical period. For this reason, it is recommended to examine the type of exterior hall plan and to discuss its application in new residential architecture.

\section{References}

\section{Books}

ALTINER, Ahmet Turan - Cüneyt Budak, Konak Kitabı, Tepe Yayınları, İstanbul 1997.

ATALAN, Özlem, Sürdürülebilir Mimaride, Kula Geleneksel Konutlarının Tasarım Anlayışı ve Yapım Malzemesi, Edebiyat, Eğitim, Sanat ve İktisat, Berikan Yayın Evi, Ankara 2018.

ATALAN, Özlem-Elif Süyük Makaklı, Türklerde Yaşama Kültürünün Değişimi; Tek Mekân Göçebe Çadırından, Minimalist Dairelere Geçiş, Sosyo-Economik Stratejiler 4: Tasarım Stratejileri, Publisher: Ijopec, 2018 Londra. 
BAMMER, Anton. Çadır ile Anadolu Evi İlişkileri İstanbul Habitat 2, Tarihten Günümüze Anadolu'da Konut ve Yerleşme, Türkiye Ekonomik ve Toplumsal Tarih Vakfi, Ofset Yayınevi, İstanbul 1996, s.243-250.

BEKTAŞ, Cengiz, Türk Evi, İstanbul: Yapı Kredi Yayınları, 1996 İstanbul.

BOZER, Rüstem, Kula Evleri, Kültür Bakanlığı Yayınları, Ankara, 1988.

ELDEM, Sedat Hakkı, Türk Evi Plan Tipleri, ITÜ Mimarlık Fakültesi, Baskı Atölyesi, İstanbul, 1968.

ELDEM, Sedat Hakk1, Türk Evi Plan Tipleri, İstanbul Teknik Üniversitesi, Mimarlık Fakültesi Yayınları, İstanbul 1955.

ELDEM, Sedat Hakkı, Türk Evi Osmanlı Dönemi, İstanbul: Türkiye Anıt Çevre Turizm Değerlerini Koruma Vakfi, İstanbul 1984.

GÜNAY, Reha, Türk Ev Geleneği ve Safranbolu Evleri, Yem Yayınları, İstanbul 1998.

KUBAN, Doğan, "Türk Ev Geleneği Üzerine Gözlemler." Türk ve İslam Sanatı Üzerine Denemeler, Arkeoloji ve Sanat yayınları, İstanbul 1982, s. 195- 209.

KUBAN, Doğan, Türk Hayatlı Evi, Eren Yayınları, İstanbul 1995.

KUBAN, Doğan, Osmanlı Mimarisi, Yem Yayın, İstanbul 2007.

KÜÇÜKERMAN, Önder, Kendi Mekanının Arayışı İçinde Türk Evi, Türkiye Turing ve Otomobil Kurumu, İstanbul 1991.

RAPOPORT, Amos "Theory, Culture and Housing,", Housing, Theory And Society, Vol. 17, No. 4, 2000, s. 145-165.

TANYELI Uğur, “Anadolu'da Bizans, Osmanlı Öncesi ve Osmanlı Dönemlerinde Yerleşme ve Barınma Düzeni”, Tarihten Günümüze Anadolu’ da Konut ve Yerleşme, Tarih Vakfı Yayınları. İstanbul 1996.

TOSUN, Yılmaz, “Milli Mimarimizde Kula Evleri”, Ticaret Matbaacılık T.A.Ş.,İzmir 1969.

YÜREKLİ Ferhan., YÜREKLİ Hülya, Türk Evi- The Turkish House, Birinci Bask1, Yem Yayın, İstanbul 2005.

\section{Articles and Thesis}

AKIN, Nur- Zeren Nuran-et al, Conservation Aimed Development Plan Report of Kula, Manisa, 1994.

AKYÜZ, Eti - Deniz Orhun, Bilge Yıldırım, Özlem Arıtan, Kuladan iki ev, Ege Mimarlık, 33, İzmir 2000.

ATALAN, Özlem A Research on the Historical Changing Process of the Coastal Settlement of the Bosphorus and its Conservation Modals; Ortaköy-Kuruçeşme Coast”, Phd Thesis, Yildiz University FBE, İstanbul 2008.

CAGDAS, Gülen, A shape grammar: The language of traditional Turkish houses. Environment and Planning B: Planning and Design 23(4), 443-464, 1996.

DERIN, Emine, Manisa İli Kula İlçesindeki Sakız Tipi Evler Ve Koruma Sorunları Üzerine Bir Araştırma, Yüksek Lisans Tezi, İstanbul 2019, s. 128-206. 
KAZMAOĞLU, Murat ve Tanyeli, Uğur, Anadolu Konut Mimarisinde Bölgesel Farklılıklar, Yapı: 33, 1979/13 İstanbul 1979.

KIRTAŞ, Esra, Evaluation Of Architectural Heritage Characteristics Of Bekirbeyler House In Kula, Manisa, Thesis Submitted To The Graduate School Of Engineering And Sciences Of Izmir Institute Of Technology In Partial Fulfilment Of The Requirements For The Degree Of Master Of Science In Architectural Restoration, 2013.

KÖSE, Abdullah, Türkiye'de Geleneksel Kırsal Konut Planlarında Göçebe Türk Kültürü İzleri, Afyon Kocatepe Üniv. Sosyal Bilimler Dergisi (Cilt 2), Afyon 2005.

\section{Web Pages}

URL 1. http://www.pulhane.com/KatalogSayfalari/k197813.html (E.T. 06.05.2020)

URL2. http://www.admimofis.com/ProjectDetails.aspx?pID=MP8Rnp3rOWM\%3D 01.05.2020) 